\title{
Exploring the Current Challenges and Opportunities of Life Cycle Sustainability Assessment
}

\author{
Rizal Taufiq Fauzi ${ }^{1, *}$, Patrick Lavoie ${ }^{2}$, Luca Sorelli ${ }^{3}$, Mohammad Davoud Heidari ${ }^{1}$ and \\ Ben Amor 1,*(D)
}

1 Department of Civil Engineering, Interdisciplinary Research Laboratory on Sustainable Engineering and Ecodesign (LIRIDE), University of Sherbrooke, Sherbrooke, QC J1K 2R1, Canada; mohammad.davoud.heidari@usherbrooke.ca

2 FPInnovations, Quebec City, QC G1P 4R4, Canada; patrick.lavoie@fpinnovations.ca

3 Department of Civil and Water Engineering, University of Laval, Quebec City, QC G1V 0A6, Canada; luca.sorelli@gci.ulaval.ca

* Correspondence: rizal.taufiq.fauzi@usherbrooke.ca (R.T.F.); ben.amor@usherbrooke.ca (B.A.); Tel.: +1-819-821-8000 (ext. 65504) (R.T.F.); +1-819-821-8000 (ext. 65504) (B.A.)

Received: 14 November 2018; Accepted: 18 January 2019; Published: 25 January 2019

\begin{abstract}
Sustainability decision making is a complex task for policy makers, considering the possible unseen consequences it may entail. With a broader scope covering environmental, economic, and social aspects, Life Cycle Sustainability Assessment (LCSA) is a promising holistic method to deal with that complexity. However, to date, this method is limited to the hotspot analysis of a product, service, or system, and hence only assesses direct impacts and overlooks the indirect ones (or consequences). This critical literature review aims to explore the challenges and the research gaps related to the integration of three methods in LCSA representing three pillars of sustainability: (Environmental) Life Cycle Assessment (LCA), Life Cycle Costing (LCC), and Social Life Cycle Assessment (S-LCA). The challenges and the research gaps that appear when pairing two of these tools with each other are identified and discussed, i.e., the temporal issues, different perspectives, the indirect consequences, etc. Although this study does not aim to remove the shadows in LCSA methods, critical research gaps are identified in order to be addressed in future works. More case studies are also recommended for a deeper understanding of methodological trade-offs that might happen, especially when dealing with the consequential perspective.
\end{abstract}

Keywords: sustainability; life cycle assessment; life cycle costing; social life cycle assessment; consequential; research gaps

\section{Introduction}

In 2015, an international agenda was agreed upon in an attempt to move society towards improved wellbeing and surroundings, through a collective plan called the Sustainable Development Goals (SDGs) [1,2]. SDGs were marked as a progressive move to achieve sustainable development involving various stakeholders in many regions. In comparison to their predecessor, Millennium Development Goals, new fields were added, addressing issues such as climate change, economic inequality, innovation, sustainable consumption, peace, and justice, among other priorities [1,3].

Sustainability challenges have attracted increasing attention over the last few decades. However, the sustainability challenges we face today are frequently seen solely in terms of environmental threats, and thus the assessment emphasizes only on this aspect [4-6]. Many tentative efforts for expanding the scope of assessment away from exclusively looking at the environmental space have been made, incorporating both economic and social aspects [6-8]. Life Cycle Assessment (LCA) is a 
powerful method for examining potential environmental impacts from the entire life cycle of a product system [9]. Now, the ideas of life-cycle thinking from LCA are being extended to other pillars, such as the economic pillar (Life Cycle Costing_LCC), the social pillar (Social Life Cycle Assessment-S-LCA), and sustainability as an entire concept (Life Cycle Sustainability Assessment—LCSA).

\subsection{Life Cycle Assessment (LCA)}

LCA seeks to quantify the potential environmental impacts of a product system based on physical energy and material flows [10]. It is believed that the first LCA study was conducted in 1969 by the Midwest Research Institute in the US for the Coca-Cola Company, for decision making on bottles packaging [11]. In 1990, the Society of Environmental Toxicology and Chemistry (SETAC) started to hold an annual conference on LCA to formulate the methodology. Three years later in 1993, the first guideline was published [12]. Since then, LCA has been in increasing development in terms of standards, methodologies, and applications.

LCA has been internationally standardized over time, from the first International Organization for Standardization (ISO) version 14040-43 (1997-2000) to the revised version ISO 14040/44 (2006) [7,9]. The United Nations Environment Program and the Society of Environmental Toxicology and Chemistry (UNEP/SETAC) Life Cycle Initiative works on the harmonization of LCA through the four stages of goal and scope definition, inventory analysis, impact assessment, and interpretation [13]. In addition to that, there exists two distinct types of LCA modeling, i.e., attributional and consequential ones. In attributional LCA (ALCA), the assessment focuses on the environmental impacts produced by the processes directly used in the assessed product system [14]. In consequential LCA (CLCA), the assessment aims to model the consequences of the changes of physical flows caused by an increasing or decreasing demand in the processes of the product system $[15,16]$.

Between attributional and consequential models, there have been several proposals to suggest the differences in terms of approaches and techniques [17,18]. However, no general consensus heads to some points of agreement. The consequential model was developed around the year 2000 as an attempt to incorporate market mechanisms (economic principles) into LCA frameworks, that the attributional model was not focusing on [17]. The main goal of the consequential model is to answer this type of question: "What are the environmental consequences of consuming X?", instead of attributional ones (such as: "What environmental impact can be attributed to product X?") [17]. This is, among other characteristics, reflected in the way CLCA address multifunctionality through system expansion, allowing the fate of the coproducts in other markets (i.e., displacements) to be included [18]. The choice of attributional and consequential method depends on the goal and scope of the study, and will influence the definition of the system boundary and its modelling [14-16]. This will potentially cause certain methodological challenges when dealing with LCSA that will be discussed in Section 2.

\subsection{Life Cycle Costing (LCC)}

LCC is a method that summarizes all the costs in the life cycle of a product that are directly assumed by one or more participants in the product system [19]. LCC was first carried out by the U.S. Department of Defense in the 1960s, for the procurement of items of military equipment that were considered to be high-cost products [20]. It emerged from the need for a comprehensive understanding of the monetary flows within the whole life cycle of a product, so that the decision making could include not merely the initial cost, but also the operation, maintenance, and end-of-life treatment costs. The general LCC concept was first defined by Blanchard [21], and later other modifications and examples were produced by organizations such as the International Organization for Standardization (ISO), the International Electrotechnical Commission (IEC), and the Australian and New Zealand National Standards (AS/NZS), which also conceptualized the total cost of the investigated product $[20,22]$. LCC has been frequently used as a cost calculation and comparison tool from a product perspective, rather than from a life cycle viewpoint, or from use of an explicitly developed methodology. 
In 2008, the European arm of the Society of Environmental Toxicology and Chemistry (SETAC-Europe) published a book [23] which was the result of its working group, in which three different categories of LCC were described: Conventional LCC, environmental LCC, and social LCC. If conventional LCC disregarded the post-production phase, while social LCC focused on indirect social costs, the environmental LCC was different. It was a mirror of LCA, which has the same definition as the assessment of entire product life cycle costs that are directly borne by one or more participants in its life cycle, with the inclusion of environmental externality costs [23]. It has generally been agreed that, among those three LCC types, environmental LCC was appropriate to be used in parallel with LCA, to support the sustainability pillars $[7,23]$. For the sake of simplicity, we will refer in this article to environmental LCC.

\subsection{Social Life Cycle Assessment (S-LCA)}

S-LCA assesses the real (site-specific) and potential, positive and negative, socio-economic impacts of a product system through its life cycle. Unlike its counterparts introduced earlier, S-LCA has a predecessor, namely Social Impact Assessment (SIA), which aimed to evaluate the social impacts of activities [24].

S-LCA does not have a long history, compared to the other two methods. Indeed, the first S-LCA guidelines from UNEP/SETAC [25] were published in 2009, in order to provide guidance to stakeholders involved in the evaluation of the social impacts of products through their lifespan. S-LCA has four phases: Goal and scope definition, inventory analysis, impact assessment, and interpretation. Some noticeable differences to environmental LCA include the high level of stakeholder involvement in the goal and scope definition, data collection, and interpretation steps, as well as the high level of sensitivity to varying geographical locations for each stage [25].

Recently, S-LCA is gaining much attention in the scientific community. It can be seen from the efforts proposed to advance the method (i.e., revisions on the current guideline, linking life cycle thinking to SDGs) and the different contexts of its application, including cutting-edge topics such as circular economy [26,27], renewable energy [28,29], and bio-based economy [30,31]. However, the gaps still exist when it is combined with other tools and it will be elaborated on more in Section 2.

\subsection{Life Cycle Sustainability Assessment (LCSA)}

The development of the LCSA framework originated from the need to incorporate the three pillars of sustainable development (environmental, economic, and social impacts) into one formulation, while retaining a life cycle perspective. There are two main formulations of LCSA. The first one is the LCSA model suggested by Kloepffer [7], which consists of LCA + LCC + S-LCA, where LCA is an ISO-conforming, environmental life cycle assessment; LCC is an LCA-type environmental life cycle costing; and S-LCA is a social life cycle assessment [7]. Second, LCSA acts as a framework, rather than a model, with a similar definition as first formulated, but with a broader and deeper scope [32]. LCSA, as proposed by Guinee et al. [32], then broadened the scope from primarily product-related subjects (product level) to subjects related to a sector (sector level) or to a whole economy. It broadened the scope of the present LCA to go beyond predominantly technological (or physical) interdependences (involving resource limitations) to cover economic and behavioral ones, thus making it possible for it to be combined with other methods, such as Material Flow Analysis, Cost-Benefit Analysis, etc. What makes it different is that, as part of broadening the scope, rather normative aspects such as discounting, weighting, and the notion of weak versus strong sustainability could be easily incorporated [33]. Both types of LCSA models (or frameworks) are included in this review.

The number of publications related to LCSA is steadily increasing, as can be seen in Figure 1. From 2007 to October 2018, 124 papers were published on the topic, as determined by the authors, by putting the keywords "Life Cycle Sustainability Assessment" and/or "LCSA", into both the Scopus database and Google Scholar (see Supplementary Materials for details on the methodology). In total, 
83 publications describing case studies and 31 publications covering other things, such as discussions of the theoretical or methodological frameworks, were found.

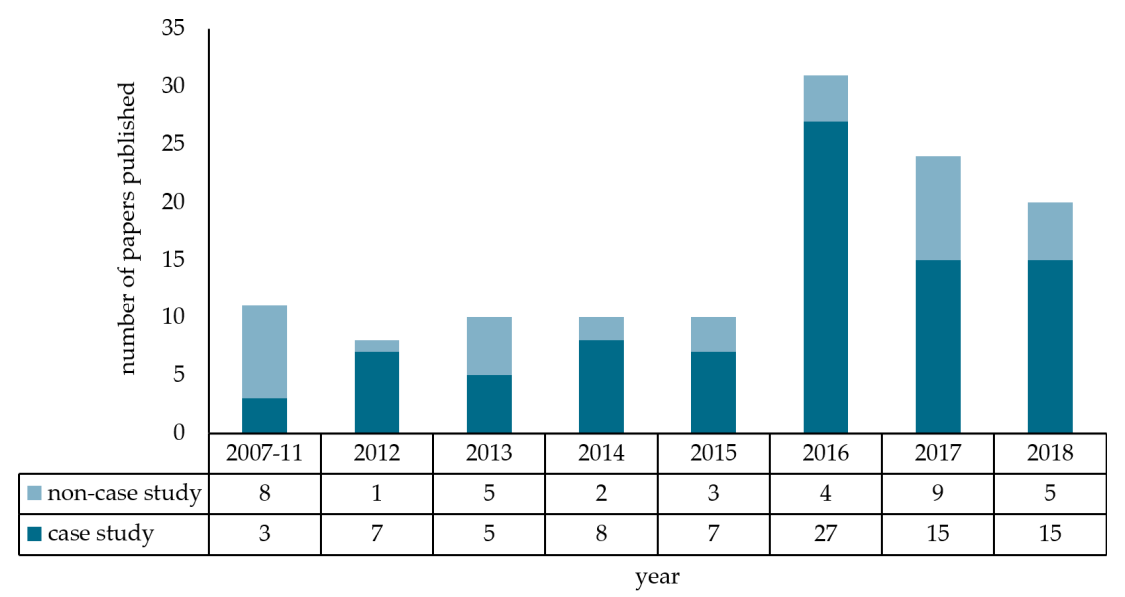

Figure 1. Life Cycle Sustainability Assessment (LCSA)-related papers published from 2007 to October 2018.

LCSA has been applied in many sectors, including transportation [34-36], building [37-39], energy [40-42], agriculture [43,44], manufacturing [45,46], and waste treatment [47-49]. The increasing number of publications on this topic, and the diverse applications of case studies, shows that LCSA is now accepted as an assessment method to support decision making on sustainability.

With the growing numbers of publications on LCSA, UNEP/SETAC [50] published a document as an introduction to the LCSA concept, and to provide guidance on putting LCSA into practice. In the guideline, the focus lays on the integration of three methods (LCA, LCC, and S-LCA) within an LCSA framework, through the presentation of various case studies. However, these three methods still have their distinctions, so they cannot be simply integrated and dovetailed with each other without some adaptation. This paper's primary objective, then, is to investigate the research challenges brought about by the integration of LCA, LCC, and S-LCA under the umbrella of an LCSA framework, and to consider these when dealing with direct and indirect impacts (i.e., consequences). This review paper, to the best knowledge of the authors, gives a novel and different angle on looking the intersecting challenges than previous review studies.

\section{Current Research Challenges in LCSA}

The following figure (Figure 2) presents the research issues that have been identified, which will be considered in the following sub-sections. 


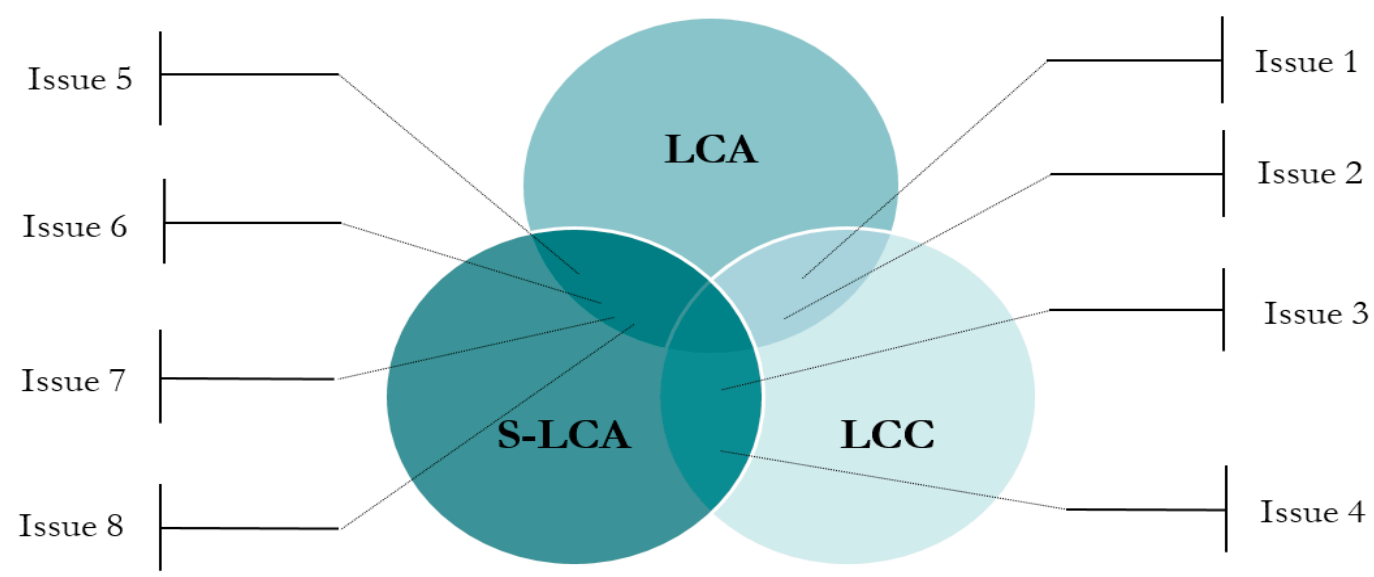

1. Temporality in LCA \& LCC

2. Consequential perspective in LCA \& LCC

3. Difference in perspective when using LCC \& S-LCA

4. Consequential perspective in LCC \& S-LCA

5. Impacts \& benefits in S-LCA compared to LCA

6. Different scale of assessment applied in S-LCA \& LCA

7. Defining what is "positive" \& "negative" in S-LCA

8. What is missing from S-LCA consequential approach

Figure 2. The methodology crossover research challenges identified in LCSA.

\subsection{The Integration of LCA and LCC}

This section focuses on the integration of LCA and LCC, and addresses pinch points caused by their integration into LCSA.

\subsubsection{Temporality in LCA and LCC (Issue 1)}

The lack of temporality is an issue in the LCA methodology that has been increasingly discussed by the scientific community [51-55]. LCA, by origin, is a steady-state framework where the temporality of the life cycle impacts is not entirely integrated into the inventory analysis or the impact assessment [54,55]. For example, when the life cycle environmental impact of a 75-year old building is assessed, certain significant hypotheses are always applied, which suggest that the electricity composition used for the construction, the operational use, and the end-of-life stage of that building does not change over time, throughout its life cycle [56]. In contrast, the temporal aspect of monetary value is embedded in LCC. With its monetary flow and the involvement of discounted monetary value, LCC is temporal by default. Hence, the cost assessment of a product system over the years should use the discounted rate to apply the temporal aspect of the changed monetary flow [23]. This discrepancy may cause an issue in LCSA case studies when LCA and LCC are combined. For example, an LCSA of a building, by Ostermeyer et al. [57], showed that the calculation used for the energy mix and the inventory data in their LCC study incorporated the discount rate for their cost flow. This meant that the future worth of a present sum of money, or a current stream of cash flow, was discounted at the considered discount rate across the given period. Ideally, this temporal integration should also be considered when dealing with current physical flows between the processes, as well as their emissions and resource use, from and to the environment. This is, however, not the case in standard LCA methodology, in which inventory results are aggregated values. By adding a temporal aspect to LCA, however, inventory results could be a function of time, where different characterization factors could consider a dynamic profile of the environmental impact.

Some effort has been made to identify the treatment of temporality in LCA and LCC, especially when a prospective change is assessed [58-60]. Heijungs et al. [61] argued critically on this, noting 
that even when LCA and LCC have identical system boundaries, they have two different ways of extracting indicators, so that any inclusion of time in these two methods must be carefully done.

For now, the temporality issue in LCA remains an open discussion in the scientific community, and is deemed to be only slightly resolved, while in LCC, it has been well implemented.

\subsubsection{Consequential Perspective in LCA and LCC (Issue 2)}

Before discussing the consequential perspective in LCSA, it is worth recapping on the main differences between consequential and attributional LCA. First, they differ in the definition of the system boundary, which was originally based on the process influenced by market change. Later, it was called affected technology or marginal technology [15]. However, a proper and consistently systematic method for determining a system boundary has not yet been established, despite the growing body of research applying and developing CLCA [14].

Unlike CLCA, LCC (environmental LCC) with the consequential perspective is not explicitly mentioned in any literature. The notion of Consequential Life Cycle Costing (CLCC) was first mentioned in a UNEP/SETAC book on Environmental Life Cycle Costing [23]. The authors argued that, for certain reasons, discussions over attributional or consequential LCA could be transferred to LCC, with a consequential approach called "LCC planning", due to its focus on supporting decision making [23]. Another application of the consequential approach within the life cycle method has also been found in a study estimating electricity pricing [62]. However, the authors reported difficulties in finding the marginal costs necessary to apply CLCC. Another argument in favor of CLCC is that the consequential model is able to incorporate indirect market mechanisms and equilibrium analyses of the market, which are aspects that are highly meaningful to the context, and yet are frequently avoided in analysis [63].

In the broader context, Sala et al. [64] pointed out a general research gap regarding the consequential approach in sustainability assessment. They argued that the notion of market resolution (i.e., region, country, etc.) also needed to be accounted for in sustainability assessments. However, they did not define the characteristics of the consequential approach in sustainability assessment, or its distinction from an attributional approach. Further examples of applications using CLCA and CLCC need to be documented.

\subsection{The Integration of LCC and S-LCA}

Concerning the integration of LCC and S-LCA, this literature review focuses on two key points: The different perspectives of the stakeholders involved and the consequential perspectives when using S-LCA. These points are discussed in the following sections.

\subsubsection{Differences in Perspective when Using Both Methods (Issue 3)}

One of the most important issues in applying S-LCA, particularly when integrated with LCC, is related to the perspective of the assessment depending on the participants concerned, within a given system boundary. Most LCC case studies in the literature primarily focused on the effect on one participant, for example, only the costs for the producer were represented in the model, and these were thus regarded as negative impacts which needed to be minimized [43,65]. For other participants, such as consumers or end-of-life managers, the perspective would be different. From an employee's standpoint, for example, hourly wages can be considered as a positive impact as, generally, higher unit labor cost in the production process would mean more income to the labor force [66]. Most LCCs that are conducted within LCSA do not consider the importance of the participant perspective [46,47]. Moreover, most S-LCA studies are carried out from perspectives different to those of the LCC. For example, in some S-LCA studies, the social impacts are seen from the perspective of the consumer, but at the same time, the costs from the consumer's viewpoint, related to the same product, do not seem to be accounted for in the LCC. This lack of consistency in perspectives makes interpretation of S-LCA and LCC results alongside each other difficult. 
As an example, an LCSA study of photovoltaic modules by Traverso et al. [67] shows the difficulty of comparing economic and social impact. Whether a product is beneficial or detrimental is subject to interpretation, based on a stakeholder's perspective, since a benefit for a company might not necessarily be a benefit for society, the company's workers, or local communities. Lu et al. [49] used different perspectives to account for the economic and social impacts of electronic waste recycling. In this study, most of the monetary value of the recycling process was quantified from the viewpoint of the recycling company as a leading participant, while on the other hand, they included the workers and the local community when looking at social aspects. In another instance, Menikpura et al. [48] applied an LCSA to assess municipal solid waste management systems, again using different participant perspectives when applying LCC and S-LCA. The participant considered in the LCC was the waste management company, while the S-LCA focused on the local community. To make a combined LCC and S-LCA assessment comprehensible and holistic for law enforcement, and to support policy initiatives, the participants in question should be the same for both methods.

\subsubsection{Consequential Perspectives in LCC and S-LCA (Issue 4)}

In Section 2.1.2, the lack of a consequential approach in LCC was partly discussed. To bring a consequential LCC into an LCSA framework, two primary considerations were suggested by Wood and Hertwich [63], reflecting on the contradictions that LCC may have and the exclusion of some relevant indicators that LCC may exhibit. Firstly, the authors argued that consequential effects in LCC must be captured in the modeling framework of LCSA to be able to understand the full dimensions of economic sustainability, by involving more pertinent indicators to avoid double-counting, i.e., the added value to the economy, through parameters that are linked to it, such as import dependency, capital and labor, and potential innovation. These parameters are the indirect effects of the added value of goods in global trade. Otherwise, the economic dimension cannot be captured holistically in LCSA. Second, it was recommended that consequential LCC was undertaken on a macro-scale, and not merely at the product level. This was because there is an inherent contradiction in that from an individual user's perspective, life cycle cost should be minimized, while from society's perspective, the sum of the components of added value should generally be maximized. On this basis, the indicators used in LCC must be carefully chosen. In addition, attempts to estimate how added value will change as a consequence of different potential decisions are not captured yet in LCC. In particular, capturing the market effect and indirect consequences in the supply chain, with different what-if scenarios, will potentially increase the knowledge gained from it.

On the other hand, consequential S-LCA has the same status as consequential LCC. Jorgensen et al. [68] and Sousa-zomer et al. [69] were the only publications that this review could identify which touched upon this issue. Jorgensen et al. [68] argued that there were three types of S-LCA, i.e., consequential, educative, and lead firm, based on the practicality of the model. Consequential S-LCA aims to see the consequences of a product decision in terms of the social wellbeing of the stakeholders, in such a way that S-LCA creates its effect by merely influencing certain production levels in companies [68]. They argued that social impacts can also occur indirectly, through the absence of action, such as a decision not to implement a specific product life cycle. This is, to some extent, different to the consequential approach in LCA, which is more focused on the incorporation of market mechanisms into the estimation of indirect consequences in its assessment. How the consequential setting was proposed to be applied in S-LCA will be reviewed in greater detail in Section 2.3.4.

Concerning the application of LCSA, the integration of a consequential perspective in both S-LCA and LCC, however, has never been proposed in the literature-only the attributional approach has. In the publications which have been reviewed, there was no evidence that the consequential concept suggested by Jorgensen et al. was followed up with any applications. 


\subsection{The Integration of S-LCA and LCA}

The application and methodology of LCA and S-LCA have reached different levels of maturity. The observed difficulties that need to be considered when integrating S-LCA and LCA in the LCSA framework are discussed in the following sub-sections.

\subsubsection{Impacts and Benefits in S-LCA Compared with LCA (Issue 5)}

There is a major difference on how we frame, and thus view, S-LCA and LCA. In the context of delivering the message, LCA is framed to assess the environmental impacts (or the negative impacts) of the resource inputs and outputs which occurred in a functioning product system [70]. On the contrary, S-LCA inherently considers any social impacts, both negative and positive [25].

In the discussion on the sustainability theme, the definition of Area of Protection (AoP) is a central focus, being a group of safeguard subjects that must be maintained for current and future generations [71]. In S-LCA, it is suggested that wellbeing is not only to be protected, but in fact promoted, while this is not the case for how AoP is defined in LCA [72]. Sustainability assessments should be assessing both the positive and negative effects of society's activities, but, as argued, this is usually not reflected, and so the positive benefits of a product are underestimated [73,74]. The focus of LCA is on assessing environmental performance through negative environmental indicators, while for S-LCA it is on evaluating social performance through indicators for both negative and positive impacts, making interpretation of a product system more challenging. For example, when Quyen and Halog [75] studied the LCA and S-LCA of rice husk-based bioelectricity, they elaborated on the difficulty of choosing the most sustainable option, due to blurred trade-offs between potential negative and positive impacts (benefits). In their summary of endpoint impacts, the potential positive impacts considered were the impacts on social wellbeing and prosperity, through the total hours of employment and of knowledge-intensive jobs. On the other hand, impacts on the environment, i.e., the loss of ecosystem biodiversity and disability-adjusted life years of human health, were regarded as potential negative impacts. The authors calculated the overall weighted summary of the results by subtracting the potential positive impacts from the potential negative impacts, by assuming that the potential positive impacts (benefits) were compensated for by the potential negative impacts.

Cihat et al. [76] also faced this trade-off while assessing the sustainability of vehicle technologies for the United States. The conflicting goal existed in the context of considering the positive impacts of the products' social aspects, as well as negative impacts from the environmental perspective. The negative environmental impacts were primarily covered in the environmental assessment methods, such as LCA, but this did not account for the potential positive environmental impacts (i.e., benefits). The latter is considered when dealing with consequential LCA. It is suggested that life cycle methods should be extended to, and enlarged from, the priority of avoiding negative impacts, and also from the intensive promotion of positive impacts (benefits) in a way that supports sustainable development $[74,77]$.

This idea of elaborating a more positive assessment by assessing environmental benefits (in addition to environmental impacts) has been initiated. A study by Norris [78] used the term "handprint", as opposed to "footprint", to quantify potential environmental benefits from a product or process. Steen and Palander [79], and Rugani [80] argued that this could be used as part of sustainability assessment. We conclude that both benefits and impacts could be part of the assessment, since improving sustainability performance is not merely a matter of reducing the risks of negative consequences, but also entails the promotion of positive benefits [79-81].

\subsubsection{Different Scales of Assessment Applied (Issue 6)}

S-LCA data could be collected through site-specific assessment or desktop screening. However, when site-specific data are not available or accessible, the use of statistical data from databases may not reflect the real situation adequately [82]. This is because most available databases reflect the country 
or sector level, which is generally contrary to LCA, where various databases are available and have been developed at a process level. For S-LCA, databases are still in their developmental stage, and this creates an important obstacle for the application of LCSA to real-life case studies [74].

This issue of data availability was noted in an LCSA study of fertilizers [43], and to cope with this difficulty, the authors collected data on three geographical scales: Country, sector, and company, for foreground processes. For background processes, only data on the sector scale were considered. They argued that country and sector data could be used as a baseline for company indicator selection, i.e., for the identification of hotspots. Consequently, the study at a company scale could then focus on these identified hotspots.

Another issue that needs to be considered in the integration of S-LCA and LCA is that not all the social indicators can be calculated as a function of the defined functional unit. A functional unit is a powerful reference to reflect the actual environmental performance of a product system [83]. While this approach has been adopted by LCC [84], S-LCA lacks this possibility, as it has both quantitative and qualitative indicators, and the latter cannot be tuned into the matrix formulation used for their calculation. It is also noted that, of the quantitative indicators, only a few could be assigned to functional units until now, for example, fair wages [85] and working hours [50].

\subsubsection{Defining What is "Positive, or Right" and "Negative, or Wrong" in S-LCA Indicators (Issue 7)}

There is a distinctly different level of confidence in the methodologies between LCA and S-LCA. A problem for impact assessment in S-LCA, which does not exist in LCA, is the ambiguous interpretation of certain indicators [7]. In LCA, we can distinguish what is right or good, and what is wrong or bad, based on the quantified environmental parameters which characterize the impacts. However, certain indicators in S-LCA are less clear-cut: For example, the low payment of workers. From a macro-perspective, as explained by Kloepffer [7], cheap labor may be a significant advantage for developing countries, enabling them to survive in the global market, which means that cheap labor also provides job opportunities. But this macro-approach may not necessarily reflect the effects on the individual, and could be said to reflect more the short-term economic advantages of the individual worker, for instance, and then the conflict arises when one considers where the line lies between fair employment compensation and slavery [86].

Another example of the ambiguous valuation of indicators concerns the feedback mechanism. For example, consumer responses to a product could be seen to be reflected by their complaints [50]. However, a boycott of a specific product may not reflect the actual negative social performance related to its life cycle. For example, this social performance is not reflected in the case of Israeli products that have been boycotted by many countries due to the political situation with Palestine, or of Moroccan oranges because of the political situation in the Western Sahara. These examples reflect the influence of a conflict that is unrelated to the immediate life cycle of the product in question. Differing views on these site-specific circumstances make the assessment more difficult. Similar examples can be found in the broader context of bioenergy policy [87]. Questions arise, such as whether benefits stemming from jobs in sugar cane farming for bioenergy are positive enough for the local community, even if the industry might increase the dependency of the local economy to the global market price of sugar cane. In another example, is new job creation in a farm-based industry good or bad if it includes new occupational fatalities? These are examples of how valuations in some assessments become more challenging [87].

Assessing social impacts is, furthermore, very context-specific and culturally dependent. Certain indicators are highly dependent on the location of the social impact. For example, absence from work can have different implications when applied to different economic or social situations [88]. If absentee rates are low, generally we can make a judgment that this indicates a good thing. However, if it is applied to a highly competitive labor market, where unwell people would go to work rather than to stay at home because they are afraid to lose their jobs, then it would indicate the opposite. Another problematic trade-off on how to evaluate potential positive impacts is what smartphones could bring 
to (especially) younger generations in certain regions, as opposed to the negative effects linked to the increased stress levels they may cause [87].

For LCA, the set of environmental indicators is well accepted by the LCA community. However, definitive targets for social performance in S-LCA are not generally agreed upon [43]. The analysis made by Finkbeiner et al. [8] of 150 different societal objectives and indicators proposed in the scientific literature showed that many topics were not coherently addressed, and that a practical methodology for social indicators cannot be directly derived for products or processes, or if they can, only a few indicators could be directly assigned to products or processes. The majority of social indicators quantify the level to which societal objectives in certain areas of life can be attained, yet they are not easily quantifiable [89].

\subsubsection{What is Missing from the S-LCA Consequential Approach (Issue 8)}

While increasingly used, S-LCA methodology is not yet irredeemably fixed [90,91]. The application of S-LCA is increasing, in both academia and the industry [92,93]. However, it has not yet incorporated a consequential approach. If CLCA aims to see the consequences of a decision on the environment, consequential S-LCA, or "C-S-LCA", is deemed capable of assessing the consequences of a decision, but not on the wellbeing of society, or in other words, on the social situation of the stakeholders involved in the product life cycle.

A suggestion was proposed for S-LCA to include quantification of the potential shifts or changes of social impacts $[68,94,95]$. In essence, this could involve assessments of shifts in behaviors, affecting stakeholders' social conditions as the life cycle progresses towards a future (or prospective) setting [95]. Efforts to capture the interdependencies of social effects in the behaviors of the stakeholders are essential, yet difficult to conduct. Certain social effects are unpredictable over time, and social indicators are mostly unrelated to the product chain. Regarding the latter, some efforts have been made in relating social indicators to social impacts in the product system, through the impact assessment step.

When looking at the impact assessment step specified in the guideline published by UNEP/SETAC, two S-LCA impact categories were proposed, based on the two different treatments of the results for subcategories $[25,94]$. Type 1 handled the resulting subcategories by aggregating them into similar topics, for which stakeholders could gain a better insight using performance reference points, while type 2 handled the resulting subcategories by incorporating causal interconnections of the social impact pathways to midpoint and end-point indicators, using a characterization factor $[25,94]$.

\section{Discussion}

LCSA is an assessment method integrating LCA, LCC, and S-LCA. Before regarding the method as settled, however, there are some research gaps which we consider to have not yet been satisfactorily bridged across each pair of methods, and thus need more attention. Looking at the integration of the three methods into LCSA, using various case studies, the identified cross-method challenges have been presented, along with directions for future research (Table 1).

\subsection{Filling the Gaps}

The challenges identified need efforts directed towards their resolution. For the temporality issue (Issue 1), some progress has been made in its clarification, with the treatment of time in LCA addressed in recent studies, highlighting dynamic life cycle inventory [96] and the characterization factor [97]. More emerging approaches are under ongoing development within the LCA community [98,99], and are ready to make progress. Having cost assessment that can be conducted by using different perspective (consumer, producer, etc.), similar issue with S-LCA (Issue 3) is expected. Some authors have realized this importance $[63,100]$, noting that points of view from different stakeholders will give more meaningful platforms from which to approach sustainability-related issues and their decision making. Additional attempts at addressing this issue are necessary for better harmonization, using, as an example, the benefits of assessing the costs of a product from two or more perspectives. 
In S-LCA, some approaches have been attempted to enhance positive assessment (Issue 5) in further studies, for example, by defining what are positive impacts [101], how to quantify them [102], and even how to achieve net positive impacts [103]. This idea of focusing on positivism in sustainability is supported by other review studies [64,74]. How available databases reflect different scales of assessment (Issue 6) has been further addressed by some authors, by regionalizing the scope of assessment, be it in an LCA at the inventory level [104], impact assessment level [105]), or S-LCA [106], and has also been confirmed by a recent review article [107]. In a recent LCA forum [108], during a discussion on regionalizing LCA, it was suggested that LCA practitioners should be more focused on rectifying spatially explicit datasets in order to have more reliable and accurate results. We hope such discussion will start for S-LCA databases as well in the future. Lastly, proposals for consensus on defining social goals are needed in regards to unclear definitions of what is good and bad in certain indicators (Issue 7), to help facilitate objectivity in the assessment.

\subsection{Research Opportunities of Consequential Approaches in LCSA}

Most research to date has focused on hotspot analyses of the sustainability performance of a product. During review of 114 published studies related to LCSA (see Supplementary Materials), we could not find any mention of consequential approaches being used. To formulate the consequences of environmental flow or of socio-economic value changes over the appointed decision made, more causal assessment is needed. This causal assessment should identify and capture direct and indirect impacts, evaluate the sustainability performance of a product system from an identical perspective, and provide feedback about what has been achieved. Causal assessment plays a vital role in the evaluation of the three sustainability pillars, as it allows us to scope out possible future developments and alternative actions. Furthermore, based on the SDGs, we believe that socio-economic factors and environmental concerns are the foci of stakeholder attention. That is, strategies such as how to alleviate poverty and how to reduce inequality have become global concerns among decision makers. However, are we ready for consequential LCSA? This question and possible answer needs further investigation.

Table 1. Summary of the research challenges and opportunities associated with the integration of Life Cycle Assessment (LCA), Life Cycle Costing (LCC), and Social Life Cycle Assessment (S-LCA), within the LCSA framework.

\begin{tabular}{|c|c|c|}
\hline Focus Area & Research Challenges (Issues) & Research Opportunities \\
\hline \multirow[b]{2}{*}{ Integration of LCA and LCC } & $\begin{array}{l}\text { Issue } 1 \text { : Temporality issue that is } \\
\text { still missing in LCA }\end{array}$ & $\begin{array}{l}\text { Capturing temporality in the environmental (resource- and emission-) flow for } \\
\text { comparison purposes, and integrating it with discounted monetary value }\end{array}$ \\
\hline & $\begin{array}{l}\text { Issue 2: Consequential perspective } \\
\text { in LCA and LCC }\end{array}$ & $\begin{array}{l}\text { Identification of consequences and indirect impacts in the intersection of } \\
\text { LCA and LCC }\end{array}$ \\
\hline \multirow{3}{*}{ Integration of LCC and S-LCA } & $\begin{array}{l}\text { Issue 3: Difference in perspective } \\
\text { when using both methods }\end{array}$ & $\begin{array}{l}\text { Proposal to exemplify economic and social assessment by incorporating } \\
\text { perspectives from different stakeholders }\end{array}$ \\
\hline & $\begin{array}{l}\text { Issue 4: Consequential perspective } \\
\text { in LCC and S-LCA }\end{array}$ & $\begin{array}{l}\text { Proposal to define and draw step-wise procedures for capturing consequential } \\
\text { approaches in LCC }\end{array}$ \\
\hline & & $\begin{array}{l}\text { Formulation of economic indicators (i.e. value-adding) that are more suitable } \\
\text { for a consequential methodology in LCC }\end{array}$ \\
\hline \multirow{8}{*}{ Integration of S-LCA and LCA } & $\begin{array}{l}\text { Issue 5: The presence of impact } \\
\text { and benefit in S-LCA, as compared } \\
\text { to LCA }\end{array}$ & $\begin{array}{c}\text { Developing more positive assessment criteria (benefits) as a way to positively } \\
\text { promote sustainability }\end{array}$ \\
\hline & & $\begin{array}{c}\text { Formulation of "area of promotion" for positive indicators, as opposed to "area } \\
\text { of protection", for both LCA and S-LCA }\end{array}$ \\
\hline & $\begin{array}{l}\text { Issue 6: The scales of assessment } \\
\text { applied in each method differs }\end{array}$ & $\begin{array}{l}\text { Proposal to develop procedures to conduct LCSA in different layers of analysis, } \\
\text { from product, sector, and country }\end{array}$ \\
\hline & & $\begin{array}{l}\text { Mapping of social impacts that can be matched and turned into a functional } \\
\text { unit of S-LCA }\end{array}$ \\
\hline & \multirow{2}{*}{$\begin{array}{l}\text { Issue 7: Unclear definition on } \\
\text { what is good or bad, in certain } \\
\text { S-LCA indicators }\end{array}$} & Developing guidelines to make social indicators more applicable \\
\hline & & $\begin{array}{c}\text { Proposal for a new consensus or agreement on unclear social goals (or targets) } \\
\text { in the regional or international context }\end{array}$ \\
\hline & $\begin{array}{l}\text { Issue 8: Absence of a } \\
\text { consequential approach in S-LCA }\end{array}$ & Incorporating the environmental and social consequences of the unit processes \\
\hline & & $\begin{array}{c}\text { Proposal to include a scheme of coherent system boundaries into S-LCA and } \\
\text { LCA, by capturing not just physical flow, for the product/service, but also the } \\
\text { corresponding interdependencies and flows of social impacts, in the } \\
\text { product chain }\end{array}$ \\
\hline
\end{tabular}




\section{Conclusions}

The identified gaps show that the harmonization of the three discussed methods (LCA, LCC, and S-LCA) within LCSA is urgently required. Further formulation of technical recommendations to conduct LCSA is desirable. We suggest further research should be focused on these technical gaps in the intersecting challenges.

Second, when applying LCSA in a policy context, we suggested that the framework needs a consequential perspective to facilitate capturing not only direct impacts but also indirect consequences. Even though the consequential LCA is not standardized and bridging the gaps in LCSA is still very much a challenge, a stepping stone to paving the road of methodological and technical development of consequential LCSA should be placed first, reflecting how sophisticated the sustainability issue is.

Third, more application of case studies is recommended as lessons learned when integrating LCA, LCC, and S-LCA, for a deeper understanding of methodological trade-offs that may happen between the three methods of sustainability assessment, especially for the causal decision. This is important since the prospective policies made by stakeholders must contribute equally to the three bottom-lines of sustainability or, at least, avoid a biased decision that is, for example, economically viable, but environmentally and socially questionable.

At the end, we alert that applying the suggested solutions on the research gaps (the research opportunities) on subsequent studies can come at the price of the increase of the time required due to the large amount of collected data. Further, it can possibly also increase the uncertainty that has to be anticipated because of possible simplification over trying to reach completeness of the study.

Supplementary Materials: The following are available online, at http:/ / www.mdpi.com/2071-1050/11/3/636/ s1, Figure S1. Methodology to find LCSA-related papers; Figure S2. Illustration of inclusion of LCSA-related papers; Table S1: Highlight of LCSA-related studies.

Author Contributions: R.T.F. performed the literature review and wrote the paper. B.A., M.D.H., P.L., and L.S. contributed to the review of the article, discussion, and conclusion of the content, and to the final edit.

Funding: The authors are grateful to the Natural Sciences and Engineering Research Council of Canada for financial support, through its ICP and CRD programs (grants IRCPJ 461745-12 and RDCPJ 445200-12), and to the industrial partners of the NSERC industrial chair on eco-responsible wood construction (CIRCERB), and the Quebec's Economy, Science and Innovation Ministry.

Conflicts of Interest: The authors declare no conflict of interest.

\section{References}

1. United Nations Sustainable Development Goals. Available online: https:/ / sustainabledevelopment.un.org/ ?menu=1300 (accessed on 6 November 2017).

2. Costanza, R.; Fioramonti, L.; Kubiszewski, I. The UN Sustainable Development Goals and the Dynamics of Well-Being. Front. Ecol. Environ. 2016, 14, 59. [CrossRef]

3. Weidema, B. SDG-LCA. Available online: https://lca-net.com/blog/2017/10/ (accessed on 7 November 2017).

4. Johnston, P.; Everard, M.; Santillo, D.; Robèrt, K. Reclaiming the Definition of Sustainability. Environ. Sci. Pollut. Res. 2007, 14, 60-66. [CrossRef]

5. Benoît, C.; Mazijn, B. Guideline for Social Life Cycle Assessment of Products; United Nations Environment Programme: Paris, France, 2009; ISBN 9789280730210.

6. Onat, N.C.; Kucukvar, M.; Halog, A.; Cloutier, S. Systems Thinking for Life Cycle Sustainability Assessment: A Review of Recent Developments, Applications, and Future Perspectives. Sustainability 2017, 9, 706. [CrossRef]

7. Kloepffer, W. Life Cycle Sustainability Assessment of Products (with Comments by Helias A. Udo de Haes, p. 95). Int. J. Life Cycle Assess. 2008, 13, 89-95. [CrossRef]

8. Finkbeiner, M.; Schau, E.M.; Lehmann, A.; Traverso, M. Towards life cycle sustainability assessment. Sustainability 2010, 2, 3309-3322. [CrossRef] 
9. The International Standards Organisation. Environmental Management_Life Cycle Assessment_Principles and Framework, 2nd ed.; The International Standards Organisation: Geneva, Switzerland, 2006; ISBN ISO 14040:2006(E).

10. The International Standards Organisation. Environmental Management_Life Cycle Assessment_Requirements and Guidelines, 1st ed.; The International Standards Organisation: Geneva, Switzerland, 2006; ISBN 5935522004.

11. Bauman, H.; Tillman, A.-M. The Hitch Hiker's Guide to LCA: An Orientation in Life Cycle Assessment Methodology and Applications, 1st ed.; Studentlitteratur AB: Lund, Sweden, 2004; ISBN1 9144023642. ISBN2 9789144023649.

12. Consoli, F.; Allen, D.; Boustead, I.; Fava, J.; Franklin, W.; Jensen, A.A.; de Oude, N.; Parrish, R.; Perriman, R.; Postlethwaite, D.; et al. Guidelines for Life-Cycle Assessment: A Code of Practice, 1st ed.; Consoli, F., Ed.; Society of Environmental Toxicology and Chemistry (SETAC): Pensacola, FL, USA, 1993; ISBN1 9056070037. ISBN2 9789056070038.

13. LCI Phase III (2012-2017): Winding down Phase 3 Flagships—Data, Methods and Product Sustainability Information. Available online: https://www.lifecycleinitiative.org/activities/phase-iii/ (accessed on 12 November 2017).

14. Zamagni, A.; Guinée, J.; Heijungs, R.; Masoni, P.; Raggi, A. Lights and shadows in consequential LCA. Int. J. Life Cycle Assess. 2012, 17, 904-918. [CrossRef]

15. Earles, J.M.; Halog, A. Consequential life cycle assessment: A review. Int. J. Life Cycle Assess. 2011, 16, 445-453. [CrossRef]

16. Curran, M.A. Life Cycle Assessment: A review of the methodology and its application to sustainability. Curr. Opin. Chem. Eng. 2013, 2, 273-277. [CrossRef]

17. Bjørn, A.; Owsianiak, M.; Laurent, A.; Olsen, S.I.; Corona, A.; Hauschild, M.Z. Scope Definition. In Life Cycle Assessment: Theory and Practice; Hauschild, M.Z., Rosenbaum, R.K., Olsen, S.I., Eds.; Springer International Publishing AG: Cham, Switzerland, 2018; pp. 75-116. ISBN 978-3-319-56474-6.

18. Brandao, M.; Martin, M.; Cowie, A.; Hamelin, L.; Zamagni, A. Consequential Life Cycle Assessment: What, How, and Why? In Encyclopedia of Sustainable Technologies; Abraham, M.A., Ed.; Elsevier Inc.: Amsterdam, The Netherlands, 2017; pp. 277-284. ISBN 9780128046777.

19. Swarr, T.E.; Hunkeler, D.; Klöpffer, W.; Pesonen, H.; Ciroth, A.; Brent, A.C.; Pagan, R. Environmental life-cycle costing: A code of practice. Int. J. Life Cycle Assess. 2011, 16, 389-391. [CrossRef]

20. Jolliet, O.; Saade-Sbeih, M.; Shaked, S.; Jolliet, A.; Crettaz, P. Environmental Life Cycle Assessment, 1st ed.; CRC Press: Boca Raton, FL, USA, 2016; ISBN 9781439887660.

21. Blanchard, B. Design and Manage to Life Cycle Cost; Dilithium Pr: Portland, ME, USA, 1978; ISBN1 978-0930206000. ISBN2 0930206002.

22. Blanchard, B.; Fabrycky, W. Systems Engineering and Analysis; Prentice Hall: Upper Saddle River, NJ, USA, 1998; ISBN1 013221735X. ISBN2 978-0132217354.

23. Hunkeler, D.; Lichtenvort, K.; Rebitzer, G. Environmental Life Cycle Costing, 1st ed.; CRC Press: Boca Raton, FL, USA, 2008; ISBN1 9781420054705. ISBN2 978-1420054705.

24. Freudenburg, W.R. Social impact assessment. Annu. Rev. Sociol. 1986, 12, 451-478. [CrossRef]

25. Benoît, C.; Mazijn, B. Guidelines for Social Life Cycle Assessment of Products—Social and Socio-Economic LCA Guidelines Complementing Environmental LCA and Life Cycle Costing, Contributing to the Full Assessment of Goods and Services within the Context of Sustainable Development; United Nations Environment Programme: Paris, France, 2009; ISBN 9789280730210.

26. Neugebauer, S.; Traverso, M.; Blengini, G.A.; Mathieux, F. Social Life Cycle Assessment of Niobium Mining in Brazil in a Circular Economy context. In Pre-Proceeding 6th Social LCA Conference People and Places for Partnership; Loeillet, D., Sanchez, C., Eds.; CIRAID: Pescara, Italy, 2018.

27. Carina, A.; Mendes, P.; Ribau, M. Social life cycle analysis as a tool for sustainable management of illegal waste dumping in municipal services. J. Clean. Prod. 2019, 210, 1141-1149. [CrossRef]

28. Corona, B.; Bozhilova-Kisheva, K.P.; Olsen, S.I.; Guillermo, S.M. Social Life Cycle Assessment of a Concentrated Solar Power Plant in Spain. J. Ind. Ecol. 2017, 21, 1566-1577. [CrossRef]

29. Tseng, Y.; Lee, Y. An Integrated Assessment Framework of Offshore Wind Power Projects Applying Equator Principles and Social Life Cycle Assessment. Sustainability 2017, 9, 1822. [CrossRef] 
30. Ra, P.; Kuppens, T.; Van Dael, M.; Azadi, H.; Lebailly, P.; Passel, S. Van Social sustainability assessments in the biobased economy: Towards a systemic approach. Renew. Sustain. Energy Rev. 2018, 82, 1839-1853. [CrossRef]

31. Falcone, P.M. Social Life Cycle Approach as a Tool for Promoting the Market Uptake of Bio-Based Products from a Consumer Perspective. Sustainability 2018, 10, 1031. [CrossRef]

32. Guinee, J.B.; Heijungs, R.; Huppes, G.; Zamagni, A.; Masoni, P.; Buonamici, R.; Ekvall, T.; Rydberg, T. Life Cycle Assessment: Past, Present, and Future. Environ. Sci. Technol. 2011, 45, 90-96. [CrossRef]

33. Guinee, J. (CML) Life Cycle Sustainability Assessment-What is it and What is its challenges. In Taking Stock of Industrial Ecology; Springer International Publishing: Cham, Switzerland, 2016; pp. 45-68. ISBN 9783319205700.

34. Cihat, N.; Kucukvar, M.; Tatari, O.; Phil, Q. Combined application of multi-criteria optimization and life-cycle sustainability assessment for optimal distribution of alternative passenger cars in U. S. the International Council on Clean Transportation. J. Clean. Prod. 2016, 112, 291-307. [CrossRef]

35. Cihat, N.; Kucukvar, M.; Tatari, O. Uncertainty-embedded dynamic life cycle sustainability assessment framework: An ex-ante perspective on the impacts of alternative vehicle options. Energy 2016, 112, 715-728. [CrossRef]

36. Onat, N.C.; Kucukvar, M.; Tatari, O.; Egilmez, G. Integration of system dynamics approach toward deepening and broadening the life cycle sustainability assessment framework: A case for electric vehicles. Int. J. Life Cycle Assess. 2016, 21, 1009-1034. [CrossRef]

37. Gencturk, B.; Hossain, K.; Lahourpour, S. Life cycle sustainability assessment of RC buildings in seismic regions. Eng. Struct. 2016, 110, 347-362. [CrossRef]

38. Hossaini, N.; Reza, B.; Akhtar, S.; Sadiq, R.; Hewage, K. AHP based life cycle sustainability assessment (LCSA) framework: A case study of six storey wood frame and concrete frame buildings in Vancouver. J. Environ. Plan. Manag. 2015, 58, 1217-1241. [CrossRef]

39. Onat, N.C.; Kucukvar, M.; Tatari, O. Integrating triple bottom line input-output analysis into life cycle sustainability assessment framework: The case for US buildings. Int. J. Life Cycle Assess. 2014, 19, 1488-1505. [CrossRef]

40. Ren, J.; Manzardo, A.; Mazzi, A.; Zuliani, F.; Scipioni, A. Prioritization of bioethanol production pathways in China based on life cycle sustainability assessment and multicriteria decision-making. Int. J. Life Cycle Assess. 2015, 20, 842-853. [CrossRef]

41. Manzardo, A.; Ren, J.; Mazzi, A.; Scipioni, A. A grey-based group decision-making methodology for the selection of hydrogen technologies in life cycle sustainability perspective. Int. J. Hydrogen Energy 2012, 37, 17663-17670. [CrossRef]

42. Stamford, L.; Azapagic, A. Life cycle sustainability assessment of electricity options for the UK. Int. J. Energy Res. 2012, 1263-1290. [CrossRef]

43. Martínez-Blanco, J.; Lehmann, A.; Muñoz, P.; Antón, A.; Traverso, M.; Rieradevall, J.; Finkbeiner, M. Application challenges for the social Life Cycle Assessment of fertilizers within life cycle sustainability assessment. J. Clean. Prod. 2014, 69, 34-48. [CrossRef]

44. Aziz, R.; Chevakidagarn, P.; Danteravanich, S. Life Cycle Sustainability Assessment of Community Composting of Agricultural and Agro Industrial Wastes. J. Sustain. Sci. Manag. 2016, 11, 57-69.

45. Peukert, B.; Benecke, S.; Clavell, J.; Neugebauer, S.; Nissen, N.F.; Uhlmann, E.; Lang, K.; Finkbeiner, M. Addressing sustainability and flexibility in manufacturing via smart modular machine tool frames to support sustainable value creation. Procedia CIRP 2015, 29, 514-519. [CrossRef]

46. Huang, B.; Mauerhofer, V. Life cycle sustainability assessment of ground source heat pump in Shanghai, China. J. Clean. Prod. 2016, 119, 207-214. [CrossRef]

47. Vinyes, E.; Oliver-Solà, J.; Ugaya, C.; Rieradevall, J.; Gasol, C.M. Application of LCSA to used cooking oil waste management. Int. J. Life Cycle Assess. 2013, 18, 445-455. [CrossRef]

48. Menikpura, S.; Gheewala, S.H.; Bonnet, S. Framework for life cycle sustainability assessment of municipal solid waste management systems with an application to a case study in Thailand. Waste Manag. Res. 2012, 30, 708-719. [CrossRef] [PubMed]

49. Lu, B.; Li, B.; Wang, L.; Yang, J.; Liu, J. Reusability based on Life Cycle Sustainability Assessment: Case study on WEEE. Procedia CIRP 2014, 15, 473-478. [CrossRef] 
50. Ciroth, A.; Finkbeier, M.; Hildenbrand, J.; Klöpffer, W.; Mazijn, B.; Prakash, S.; Sonnemann, G.; Traverso, M.; Ugaya, C.M.; Valdivia, S.; Vickery-Niederman, G. Towards a Life Cycle Sustainability Assessment: Making Informed Choices on Products, 1st ed.; Valdivia, S., Ugaya, C.M.L., Sonnemann, G., Hildenbrand, J., Eds.; United Nations Environment Programme: Paris, France, 2011; ISBN 9789280731750.

51. Levasseur, A.; Lesage, P.; Margni, M.; Deschênes, L.; Samson, R. Considering Time in LCA: Dynamic LCA and Its Application to Global Warming Impact Assessments. Environ. Sci. Technol. 2010, 44, 3169-3174. [CrossRef] [PubMed]

52. Mcmanus, M.C.; Taylor, C.M. The changing nature of life cycle assessment. Biomass Bioenergy 2015, 82, 13-26. [CrossRef] [PubMed]

53. Yuan, C.; Wang, E.; Zhai, Q.; Yang, F. Temporal discounting in life cycle assessment: A critical review and theoretical framework. Environ. Impact Assess. Rev. 2015, 51, 23-31. [CrossRef]

54. Zhai, Q.; Crowley, B.; Yuan, C. Temporal Discounting for Life Cycle Assessment: Differences between Environmental Discounting and Economic Discounting. In Proceedings of the 2011 IEEE International Symposium on Sustainable Systems and Technology, Chicago, IL, USA, 16-18 May 2011.

55. Amor, B.; Gaudreault, C.; Pineau, P.; Samson, R. Implications of integrating electricity supply dynamics into life cycle assessment: A case study of renewable distributed generation. Renew. Energy 2014, 69, 410-419. [CrossRef]

56. Anand, C.K.; Amor, B. Recent developments, future challenges and new research directions in LCA of buildings: A critical review. Renew. Sustain. Energy Rev. 2017, 67, 408-416. [CrossRef]

57. Ostermeyer, Y.; Wallbaum, H.; Reuter, F. Multidimensional Pareto optimization as an approach for site-specific building refurbishment solutions applicable for life cycle sustainability assessment. Int. J. Life Cycle Assess. 2013, 18, 1762-1779. [CrossRef]

58. Beloin-saint-pierre, D.; Heijungs, R.; Blanc, I. The ESPA (Enhanced Structural Path Analysis) method: A solution to an implementation challenge for dynamic life cycle assessment studies. Int. J. Life Cycle Assess. 2014, 16, 861-871. [CrossRef]

59. Field, F.; Kirchain, R.; Clark, J. Life-Cycle Assessment and Temporal Distributions of Emissions Developing a Fleet-Based Analysis. J. Ind. Ecol. 2000, 4, 71-91. [CrossRef]

60. Shah, V.P.; Ries, R.J. A characterization model with spatial and temporal resolution for life cycle impact assessment of photochemical precursors in the United States. Int. J. Life Cycle Assess. 2009, 14, $313-327$. [CrossRef]

61. Heijungs, R.; Huppes, G.; Guinée, J.B. Life cycle assessment and sustainability analysis of products, materials and technologies. Toward a scientific framework for sustainability life cycle analysis. Polym. Degrad. Stab. 2010, 95, 422-428. [CrossRef]

62. Amor, B.; Billette, E.; Villemeur, D.; Pellat, M.; Pineau, P. Influence of wind power on hourly electricity prices and GHG (greenhouse gas) emissions: Evidence that congestion matters from Ontario zonal data. Energy 2014, 66, 458-469. [CrossRef]

63. Wood, R.; Hertwich, E.G. Economic modelling and indicators in life cycle sustainability assessment of Products. Int. J. Life Cycle Assess. 2013, 18, 1710-1721. [CrossRef]

64. Sala, S.; Farioli, F.; Zamagni, A. Life cycle sustainability assessment in the context of sustainability science progress (part 2). Int. J. Life Cycle Assess. 2013, 18, 1686-1697. [CrossRef]

65. Akhtar, S.; Reza, B.; Hewage, K. Life cycle sustainability assessment (LCSA) for selection of sewer pipe materials. Clean Technol. Environ. Policy 2015, 17, 973-992. [CrossRef]

66. Valdivia, S.; Ugaya, C.M.L.; Sonnemann, G. Life Cycle Sustainability Assessment: From LCA to LCSA-A UNEP/SETAC approach towards a life cycle sustainability assessment-Our contribution to Rio + 20. Int. J. Life Cycle Assess. 2013, 18, 1673-1685. [CrossRef]

67. Traverso, M.; Asdrubali, F.; Francia, A.; Finkbeiner, M. Towards life cycle sustainability assessment: An implementation to photovoltaic modules. Int. J. Life Cycle Assess. 2012, 17, 1068-1079. [CrossRef]

68. Jørgensen, A.; Finkbeiner, M.; Jørgensen, M.S.; Hauschild, M.Z. Defining the baseline in social life cycle assessment. Int. J. Life Cycle Assess. 2010, 15, 376-384. [CrossRef]

69. Sousa-zomer, T.T.; Miguel, P.A.C. The main challenges for social life cycle assessment (SLCA) to support the social impacts analysis of product-service systems. Int. J. Life Cycle Assess. 2015, 23, 607-616. [CrossRef]

70. Clift, P.R. Social life cycle assessment: What are we trying to do? In Pre-Proceedings of the 4th International Seminar on Social LCA; CIRAD: Montpellier, France, 2014; pp. 11-16. 
71. Schaubroeck, T. A Revision of What Life Cycle Sustainability Assessment Should Entail Towards Modeling the Net Impact on Human Well-Being. J. Ind. Ecol. 2017, 21, 1-14. [CrossRef]

72. Dreyer, L.C.; Hauschild, M.Z.; Schierbeck, J. A Framework for Social Life Cycle Impact Assessment. Int. J. Life Cycle Assess. 2006, 11, 88-97. [CrossRef]

73. Hacking, T.; Guthrie, P. A framework for clarifying the meaning of Triple Bottom-Line, Integrated, and Sustainability Assessment. Environ. Impact Assess. Rev. 2008, 28, 73-89. [CrossRef]

74. Sala, S.; Farioli, F.; Zamagni, A. Progress in sustainability science: Lessons learnt from current methodologies for sustainability assessment: Part 1. Int. J. Life Cycle Assess. 2013, 18, 1653-1672. [CrossRef]

75. Quyen, L.; Halog, A. Rice husk based bioelectricity vs. Coal-fired electricity: Life cycle sustainability assessment case study in Vietnam. Procedia CIRP 2016, 40, 73-78. [CrossRef]

76. Cihat, N.; Gumus, S.; Kucukvar, M.; Tatari, O. Application of the TOPSIS and intuitionistic fuzzy set approaches for ranking the life cycle sustainability performance of alternative vehicle technologies. Sustain. Prod. Consum. 2016, 6, 12-25. [CrossRef]

77. Zamagni, A.; Pesonen, H.; Swarr, T. From LCA to Life Cycle Sustainability Assessment: Concept, practice and future directions. Int. J. Life Cycle Assess. 2013, 18, 1637-1641. [CrossRef]

78. Norris, G.A. Doing More Good than Harm: Footprints, Handprints, and Beneficience. Available online: http:/ /www.fusbp.com/wp-content/uploads/2010/09/Basic-Beneficience-Primer-Handprintaccounting.pdf (accessed on 6 November 2017).

79. Steen, B.; Palander, S. Life Cycle Sustainability Assessment A selection of safeguard subjects and state indicators for sustainability assessments. Int. J. Life Cycle Assess. 2016, 21, 861-874. [CrossRef]

80. Rugani, B.; Benetto, E.; Igos, E.; Quinti, G.; Declich, A.; Feudo, F. Techniques Matériaux towards prospective life cycle sustainability analysis: Exploring complementarities between social and environmental life cycle assessments for the case of Luxembourg's energy system. Matér. Tech. 2015, 102, 605. [CrossRef]

81. Ekener, E.; Hansson, J.; Larsson, A.; Peck, P. Developing Life Cycle Sustainability Assessment methodology by applying values-based sustainability weighting-Tested on biomass based and fossil transportation fuels. J. Clean. Prod. 2018, 181, 337-351. [CrossRef]

82. Traverso, M.; Finkbeiner, M.; Jørgensen, A.; Schneider, L. Life Cycle Sustainability Dashboard. J. Ind. Ecol. 2012, 16, 680-688. [CrossRef]

83. Heijungs, R.; Sangwon, S. The Computational Structure of Life Cycle Assessment; Springer: Dordrecht, The Netherlands, 2002.

84. Heijungs, R.; Settanni, E.; Guinée, J. Toward a computational structure for life cycle sustainability analysis: Unifying LCA and LCC. Int. J. Life Cycle Assess. 2013, 18, 1722-1733. [CrossRef]

85. Neugebauer, S.; Finkbeiner, M.; Emara, Y.; Hellerstr, C. Calculation of Fair wage potentials along products' life cycle e Introduction of a new midpoint impact category for social life cycle assessment. J. Clean. Prod. 2017, 143. [CrossRef]

86. Weidema, B.P. The Integration of Economic and Social Aspects in Life Cycle Impact Assessment. Int. J. Life Cycle Assess. 2006, 11, 89-96. [CrossRef]

87. Waldekker, B.; Molnar, S. Social LCA at SP-Challenges and Opportunities; SP Sveriges Tekniska Forskningsinstitut: Boras, Sweden, 2014.

88. Grießhammer, R.; Buchert, M.; Hochfeld, C. PROSA_Product Sustainability Assessment; Öko-Institut e.V.: Freiburg, Germany, 2007; Volume 49.

89. Halog, A.; Manik, Y. Advancing Integrated Systems Modelling Framework for Life Cycle Sustainability Assessment. Sustainability 2011, 3, 469-499. [CrossRef]

90. Traverso, M. Is social life cycle assessment really struggling in development or is it on a normal path towards harmonization/standardization? Int. J. Life Cycle Assess. 2018, 23, 199-200. [CrossRef]

91. Iofrida, N. Why social life cycle assessment is struggling in development? Int. J. Life Cycle Assess. 2017, 23, 201-203. [CrossRef]

92. Arcese, G.; Lucchetti, M.C.; Massa, I.; Valente, C. State of the art in S-LCA: Integrating literature review and automatic text analysis. Int. J. Life Cycle Assess. 2016, 23, 394-405. [CrossRef]

93. Wu, R.; Yang, D.; Chen, J. Social Life Cycle Assessment Revisited. Sustainability 2014, 6, 4200-4226. [CrossRef]

94. Macombe, C.; Leskinen, P.; Feschet, P.; Antikainen, R. Social life cycle assessment of biodiesel production at three levels: A literature review and development needs. J. Clean. Prod. 2013, 52, 205-216. [CrossRef] 
95. Parent, J.; Cucuzzella, C.; Revéret, J. Revisiting the role of LCA and SLCA in the transition towards sustainable production and consumption. Int. J. Life Cycle Assess. 2013, 18, 1642-1652. [CrossRef]

96. Kono, J.; Ostermeyer, Y.; Wallbaum, H. The trends of hourly carbon emission factors in Germany and investigation on relevant consumption patterns for its application. Int. J. Life Cycle Assess. 2017, 2015, 1493-1501. [CrossRef]

97. Su, S.; Li, X.; Zhu, Y.; Lin, B. Dynamic LCA framework for environmental impact assessment of buildings. Energy Build. 2017, 149, 310-320. [CrossRef]

98. Cardellini, G.; Mutel, C.L.; Vial, E.; Muys, B. Science of the Total Environment Temporalis, a generic method and tool for dynamic Life Cycle Assessment. Sci. Total Environ. 2018, 645, 585-595. [CrossRef] [PubMed]

99. Shimako, A.H.; Tiruta-barna, L.; Barbara, A.; De Faria, A.B.B.; Ahmadi, A.; Spérandio, M. Science of the Total Environment Sensitivity analysis of temporal parameters in a dynamic LCA framework. Sci. Total Environ. 2018, 624, 1250-1262. [CrossRef] [PubMed]

100. Moreau, V.; Weidema, B.P. The computational structure of environmental life cycle costing. Int. J. Life Cycle Assess. 2015, 20, 1359-1363. [CrossRef]

101. Indrane, D.; Goedkoop, M.; de Beer, I. Consistent Assessment of Positive Impacts. In Pre-Proceeding 6th Social LCA Conference People and Places for Partnership; Loeillet, D., Catherine Sanchez, Eds.; CIRAD: Pescara, Italy, 2018; pp. 18-21.

102. Ekener, E.; Mokeeva-Hansson, E.; Macombe, C. To assess use phase impacts in S-LCA. In Pre-Proceeding 6th Social LCA Conference People and Places for Partnership; Loeillet, D., Sanchez, C., Eds.; CIRAD: Pescara, Italy, 2018; pp. 13-17.

103. Benoit-Norris, C.; Norris, G.A.; Azuero, L. Structure of a Net Positive analysis for supply chain social impacts. In Pre-Proceeding 6th Social LCA Conference People and Places for Partnership; Loeillet, D., Sanchez, C., Eds.; CIRAD: Pescara, Italy, 2018; p. 12.

104. Yang, Y. Toward a more accurate regionalized life cycle inventory. J. Clean. Prod. 2016, 112, 308-315. [CrossRef]

105. Loiseau, E.; Aissani, L.; Le Féon, S.; Laurent, F.; Cerceau, J.; Sala, S.; Roux, P. Territorial Life Cycle Assessment (LCA): What exactly is it about? A proposal towards using a common terminology and a research agenda. J. Clean. Prod. 2018, 176, 474-485. [CrossRef]

106. Siebert, A.; Bezama, A.; Keeffe, S.O.; Thrän, D. Social life cycle assessment: In pursuit of a framework for assessing wood-based products from bioeconomy regions in Germany. Int. J. Life Cycle Assess. 2018, 23, 651-662. [CrossRef]

107. Martin, M.; Røyne, F.; Ekvall, T.; Moberg, Å. Life Cycle Sustainability Evaluations of Bio-based Value Chains: Reviewing the Indicators from a Swedish Perspective. Sustainability 2018, 10, 547. [CrossRef]

108. Margni, M.; Mutel, C.; Reinhard, J.; Stolz, P.; Van Zelm, R.; Vieira, M. Regionalization in LCA: Current status in concepts, software and databases -69th LCA forum, Swiss Federal Institute of Technology, Zurich, 13 September, 2018. Int. J. Life Cycle Assess. 2018. [CrossRef]

(C) 2019 by the authors. Licensee MDPI, Basel, Switzerland. This article is an open access article distributed under the terms and conditions of the Creative Commons Attribution (CC BY) license (http:/ / creativecommons.org/licenses/by/4.0/). 